DOI:10.17951/h.2019.53.2.25-35

\begin{tabular}{lc}
\hline & A N N A L E S \\
UNIVERSITATIS & MARIAE CURIE-SKŁODOWSKA \\
LUBLIN - POLONIA & SECTIOH H \\
VOL. LIII, 2 & 2019 \\
\hline
\end{tabular}

\author{
JOANNA HERNIK \\ joanna.hernik@zut.edu.pl \\ West Pomeranian University of Technology in Szczecin, Faculty of Economics, \\ al. Piastów 17, 70-310 Szczecin, Poland \\ ORCID ID: https://orcid.org/0000-0001-8895-6039
}

\title{
Nomen omen: Recent trends in company names
}

Keywords: hairdressing services; small businesses; communication; language

JEL: M1; M3; Z13

How to quote this paper: Hernik, J. (2019). Nomen omen: Recent trends in company names. Annales Universitatis Mariae Curie-Skłodowska, sectio H-Oeconomia, Vol. 53, No. 2.

\begin{abstract}
Theoretical background: It is a well-known fact that a name should be original and distinguish a business from the competition. It should also meet several other criteria, such as being easy to pronounce and remember, and being connected with the specifics of the company's operations. Company names, as with any other names, are important because people react to a word the same way they react to the object this name denotes. Therefore, the length of a company name and the words it contains are important. Moreover, in the marketing nomenclature what carries the most significance is not the word itself but the so-called connotation, i.e. the direct reference to the object of the word and the entire set of features connected with it. When creating their own company names, entrepreneurs often use this aspect to better communicate with their target audience. This is enforced by both the growing competition and the expectations of consumers. In recent years, considerable innovativeness can be observed on the part of entrepreneurs who depart from traditional terms and decide on unusual names.

Purpose of the article: The following article presents trends in Polish company names from the perspective of marketing efficiency on the one hand, and linguistic innovation on the other. The purpose of the article is to determine the kind of linguistic changes and their assessment from the viewpoint of communication effectiveness.

Research methods: The empirical section includes the analysis of 247 names of companies that provide hairdressing services, while the theoretical section concerns the issues of creating a brand and the lexical
\end{abstract}


side of it. In particular, the considerations concern the linguistic norms and marketing principles behind creating company names.

Main findings: The findings indicate that the names ceased to be original but from a marketing perspective they became more effective. The names became more efficient in terms of marketing communication, for example, the words "studio" and "academy" (studio or akademia in Polish) carry a lot of content and connote expertise, knowledge and elite. Of course, the name and surname of an owner (which were popular in the past for hairdressing companies' names) does not include such information. Of further interest is that foreign sounding words have also disappeared almost completely; in particular, the number of words from English has decreased. Therefore, by using words with a more universal meaning and domestication in the Polish language, a company evokes positive reactions and associations, which are very important in the first contact between a customer and a company.

\section{Introduction}

According to a dictionary definition, the phrase nomen omen refers to a situation in which we notice a connection between a given phrase and something else. It can be translated as the name is a sign, and so the implication is that knowing the name of something can already tell us a lot about it. In other words, the name characterises the person or thing in question (Stownik Języka Polskiego PWN). In marketing activities, company names play a significant role. They can refer to individual products, entire series or categories of products or the companies themselves. Frequently, the consumer's likeliness to be interested in an offer at first contact depends on the name, as it can introduce emotions (fulfilment of dreams) or benefits (material or immaterial). A good name can thus facilitate success on the market (Spiro, 2010; Zboralski, 2000, pp. 11-12).

Previously, ways of creating names were based on several rules such as: the name has to be easy to pronounce, have good connotations and be related to the profile of the company. However, the resources and options offered by a native language may be insufficient, especially as far as the internationalisation of economy is concerned, so certain trends and linguistic innovations can be observed in company and product names. The following article concerns the new tendencies observed in the creation of company names, and the objective is to determine the type of linguistic changes and their assessment from the point of view of their marketing effectiveness. To evaluate the originality of names, the concept of Alserhan and Alserhan (2012) was used, as discussed later in this work.

\section{Literature review}

Names are the basis of distinguishing between products and companies. According to Zboralski (2000, p. 14), naming consists of creating and solidifying connections between a word and an object, and so a name is a linguistic representative of an object or a phenomenon. From the language point of view, names can be common 
(generic) or individual (proper names). Generic names denote a certain set of objects or a class of phenomena (e.g. shoes, art) which are recognisable as a result of human knowledge and experience. Proper names, on the other hand, refer to particular things, persons and objects that are unique and about which the speaker knows something (e.g. Narutowicz, Florida, reinette). It is worth noting that proper names are often spelled with a capital letter, which emphasises this individuality and uniqueness (Rotfeld, 2008, pp. 121-122).

The key issue in creating a name is its originality, which allows the company to distinguish itself on the market. An "original" name can therefore be understood as one that is not an imitation or modification of something else; it is one of a kind (Stownik Języka Polskiego $P W N$ ). In the literature there is a lack of studies on small enterprises' names, therefore, the purpose of this article is to determine the type of linguistic changes and their assessment from the viewpoint of effective marketing. From this perspective, Alserhan and Alserhan (2012) divide company names into four categories: champions (zero similarity), runners-up (low similarity), wannabes (high similarity) and washouts (extreme similarity). The methods of content analysis and comparative analysis were used in the study. The presented analysis refers to language changes, and it should be stated here that in terms of communication effectiveness, the study can be strengthened further by the opinions of clients. That said, industry analyses are encountered in the literature, and so the method adopted here (hairdressers' industry study) is used by other researchers (Wilson \& Huang, 2003, pp. 52-63).

Moving on to discuss innovation in language - that is, new elements in word formation or phraseology - it should be mentioned that linguistic innovations may be formed unconsciously, as a result of the ignorance of linguistic rules, or consciously, as a result of the need to name something new. Initially, the changes are used in everyday language - colloquial speech and informal contacts. Next, if, owing to their semantic and stylistic value, they are accepted by language users, they enter official language (the so-called model norm).

The basic question that entrepreneurs ask themselves is how customers react to marketing activities, including offered products and their names (Andruszkiewicz, 2011, pp. 147-152). The recipient will seek a certain promise in the name, related to their desired values (Chmielewska-Muciek, 2017). The practice of creating names results from certain interactions between the entrepreneur (owner) and the society, their knowledge and the process of perception. In some cases, especially in start-ups, the discussion may centre on co-creating a company name, as it can be invented with input from the shareholders (Fox, 2011). However, more commonly the name is simply invented and registered by the founder of the company. It seems that the former respect the consumers have had for brands seems to be in decline. Saunders and Guoqun (1996) claim that nowadays, consumers want something new and surprising; they are no longer satisfied with names merely being incorporated into company names, therefore, brand management must be more innovative and look for new solutions. 


\section{Research methodology}

As has already been mentioned, the article discusses new tendencies observed in the creation of company names. The purpose of the article is to determine the type of linguistic changes and their assessment from the perspective of effective marketing, the thesis being that entrepreneurs search for original (unique) names to distinguish themselves on the market but they are motivated by linguistic trends and not actual originality.

Two hundred and seventy four names of hairdressing salons located throughout Poland served as empirical material. The names were obtained from the National Court Register (KRS) by two methods: first, from 1,350 companies which contained the word fryzjer (hairdresser), 130 names were randomly selected; second, companies without the word fryzjer in the name but with the words wtos or wtosy (a hair or hair) were all analysed, totalling 144. The methods of content analysis and comparative analysis were used in the study.

\section{Results}

Company names, as with all other names, are important because people react to a word in the same way that they react to the object it denotes (Zboralski, 2000, p. 19). Therefore, the length of a company name and the words it contains are important. As has been mentioned, a total of 274 hairdressing salons were analysed and, significantly, only half of those companies are zaktady (establishments), as the other half abandoned the traditional expression and opted for more sophisticated solutions.

\section{Analysis of names in group A}

Among 130 companies with the word fryzjer (and its declinations), over a quarter (26\%) of the names includes the target group, defining whether the establishment is for women, men or both. It is common for those companies to have entire names and surnames of their owners in the name - in the case of the studied hairdressing salons, $50(38.5 \%)$ contained such an element. Slightly fewer company names, 33\% (43 businesses), contained information indicating that the provided service was mobile. Apart from the information on mobility and the owner's name, the names of some establishments contained words of foreign origin: $17.7 \%$ had borrowings from English, while $20.8 \%$ had borrowings from other languages. In total, 50 names (38.5\%) contained words which could be considered foreign sounding, such as New Look, Mrs. Barber or Sensual. It should be noted that there were not only English borrowings but also words such as Aksios - a Greek term meaning "worthy" (also "acclamation" in the Eastern church), or Figaro - a name from Mozart's opera The 
Marriage of Figaro. Among 130 names, only 17 (13.1\%) indicated the place of service, e.g. Fryzjer Ogrodowy (Garden Hairdresser) or U Ciebie w Domu (At Your Place). Sixteen names (12.3\%) said something about the quality or feature of the provided services. They included names such as: Fryzjer z Pasja (Haidresser with a Passion), Cieccie w Locie (Haircut on the Fly), Naturalny Szyk (Natural Chic) or SPA dla Włosów (Hair SPA). Some names (6.6\%) suggested a readiness to befriend their customers through diminutives or familiarised names, e.g. Anet, Dżudi or Graża. Finally, some names (5.4\%) contained humorous phrases, such as Rach Ciach (Snip Snip). This aspect is presented in Figure 1.

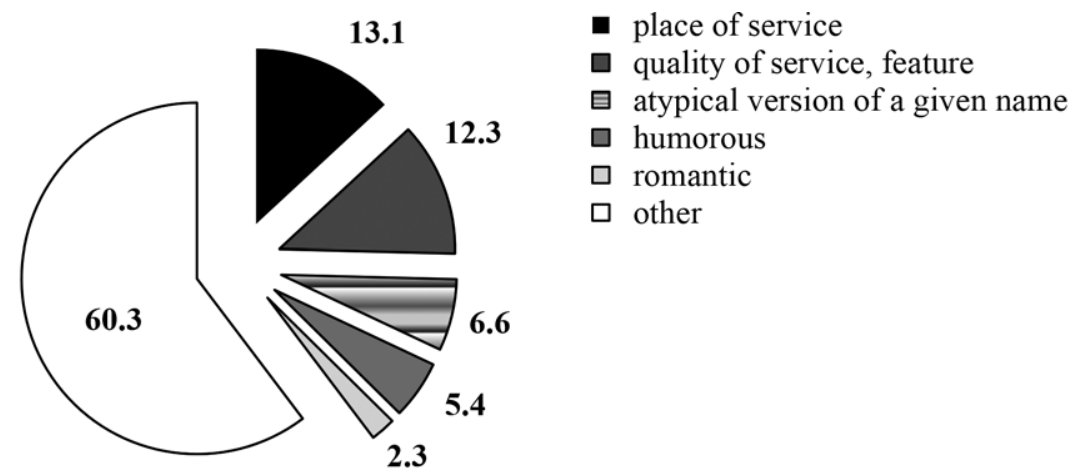

Figure 1. Elements in company names of hairdressers (group A) (in \%)

Source: Author's own study.

In the studied group of 130 hairdresser establishments, 60 (46.2\%) fall into the category of unique names (zero similarity). The originality of names results from an atypical combination of words and thus the creation of a new phraseme, or from including an expression not connected with hairdressing in the name. This category included names such as Cięcie w Locie (Haircut on the Fly), Fryzjer Mobilny (Mobile Hairdresser), Barber's Point and Fryzjer Męski na Kwadracie, Fryzjer Damsko-Męski Cyrulik ("Barber" Unisex Hairdresser). In the second group (low similarity) there are establishments whose names contain either the specifics of the service and the name and surname of the owner, or a name that is original from the point of view of the Polish language. They include: Mobilny Fryzjer Venus (Venus Mobile Hairdresser), Ekspresja Fryzjer Damsko Męski Iwona Franke (Expression Iwona Franke, Unisex Hairdresser) and Mobilny Fryzjer Nefre (Nefre Mobile Hairdresser). In total, 46 such cases were distinguished, constituting $35.4 \%$ of all analysed names. The following two categories, high similarity and extreme similarity, contained $8(6.2 \%)$ and 16 $(12.4 \%)$ names, respectively. Those names contained either first names only, as in Fryzjer Damski u Justyny (At Justyna's Women Hairdresser), or only indications about the operation, such as Fryzjer-Stylista (Hairdresser-Stylist) or Mobilny Fryzjer (Mobile Hairdresser) (Figure 2). 


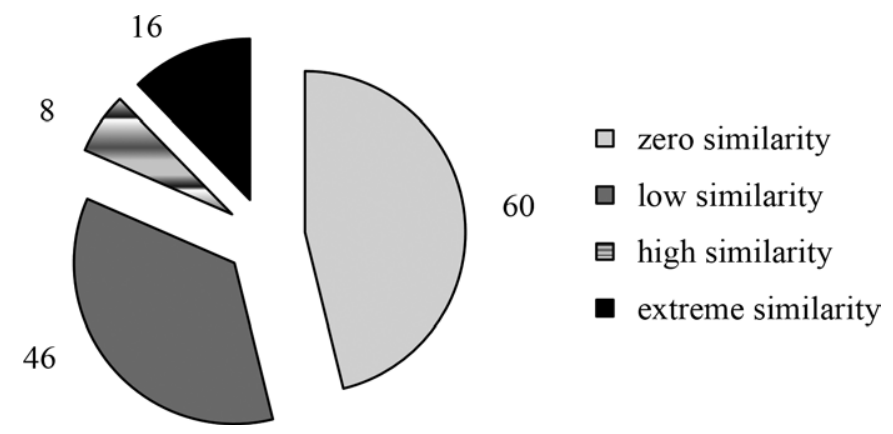

Figure 2. Division of hairdresser's names from the point of view of the name's originality (group A)

Source: Author's own study.

\section{Analysis of names in group B}

As mentioned earlier, the second group of analysed names (Figure 3) are those which do not contain the word fryzjer but have the word wlos (wtosy). One hundred and forty-four such names were distinguished. Characteristic of this group were names with information about the place of service - be it a studio, a salon, a workshop, a gallery or an academy (e.g. Studio Zdrowego Włosa - Healthy Hair Studio). Such information was provided by 102 companies (70.8\%). The owners also emphasise the uniqueness of their businesses and call their establishments Akademia Pięknych Włosów (Academy of Beautiful Hair), Światynia Włosa (Temple of Hair) and even Raj dla Wlosa (Paradise for Hair). However, it is much less common than in the previous group to encounter names describing a feature of the service or its mobility. Foreign sounding words also disappeared almost completely, although many companies used words which came into Polish from other languages and became

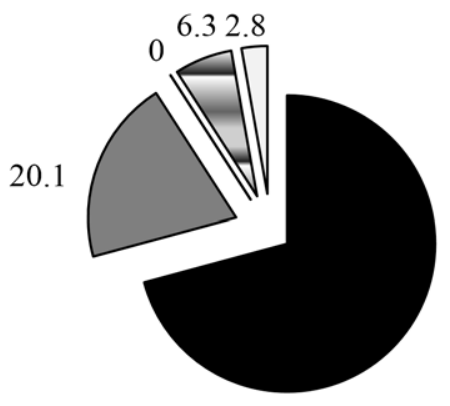

- place of service

$\square$ quality of service, feature

$\square$ atypical version of a given name - none

$\square$ humorous - none

日 romantic

$\square$ other

Figure 3. Elements in the names of hairdressing establishments (group B) (in \%) 
assimilated. Among the examples are academy (of Greek origin), institute (Latin), salon (Italian), stylization (French), etc. In this group, the most commonly used word of foreign origin was studio, with 29 names (20.14\%).

In the studied group, considering the aforementioned division into zero, low, high and extreme similarity, the uniqueness of names was also analysed (Figure 4).

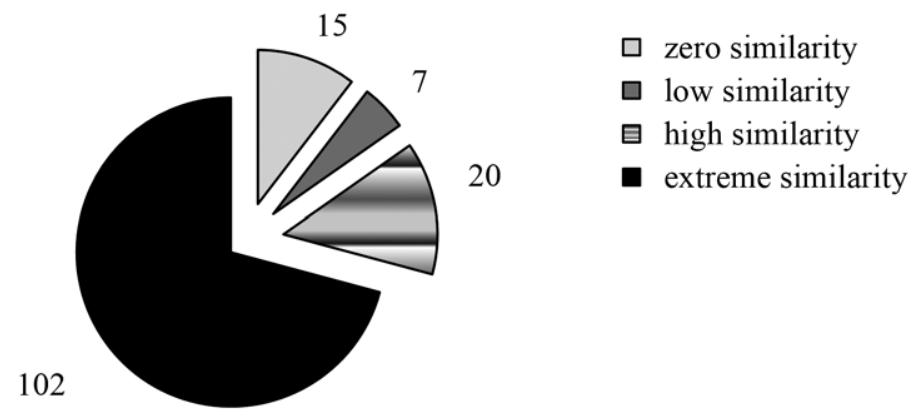

Figure 4. Division of names of hairdressing salons from the point of view of the name's originality (group B)

Source: Author's own study.

The results of the analysis indicate that names have lost much of their originality. In the former group of hairdressing salons, when the name often contained the first and last name of the owner, $46.2 \%$ of names could be considered original. In the second group, the use of proper names disappeared, while studios, academies, clinics and salons dominate. There are few really original (and, thus, unique) names -15 (10.4\%). In this group of names, there are no indications of the target group and so nothing to indicate whether it is a women's salon or a barbershop.

\section{Discussion}

It should be remembered that the name of a company or a product evokes subconscious, automatic and immediate reactions. Moreover, in the marketing nomenclature what means the most is not the word itself, but the so-called connotation, i.e. how the word directly references the object and the entire set of features connected with it. Everyone is aware that a name is intentional, and so its author wanted to communicate something. Most often, this message is information combined with a promise, suggestion and emotions. Persuasion via name consists thus of the multi-layered impact of words used in the name (Zboralski, 2000, p. 67). In the analysed names, the innovation applies to spheres, such as searching for new expressions for the location of the service or linking the name with professionalism. Entrepreneurs try to achieve this through formulating new phrasemes (unobvious 
combination of words) and also through the choice of words connected with something special; high society; the elite. As the results of the analysis demonstrate, in the first group of names (group A), the uniqueness was connected with the presence of the owner's first and last name in the company name. In the second group (B), the owners sought uniqueness through unobvious definitions of the place of hairdressing service, such as studio $(20.14 \%)$, academy $(5.5 \%)$, clinic $(5.5 \%)$ or institute (3.5\%). In their company names they also highlighted that it is stylization $(3.5 \%)$, and so giving style to hair. It can be concluded that the names in the latter group sound better, although they are not original. This results from the aforementioned connotations and so an entire spectrum of terms are evoked in the recipient's minds upon seeing a given word. Therefore, an academy is a place of education and knowledge, and so is an institute - a scientific research unit; a clinic is a place of assistance and improvement; and a salon is the best, most representative room in an apartment.

Changes (innovations) in language are connected with changes in other spheres of human activity. In the case of economic operations, this concerns globalisation and modern technologies. Innovation in language may appear as a new way of pronouncing a familiar word or its new connection with another word, or, finally, the appearance of an entirely new word (Dell'Era et al., 2008). Linguistic innovations are most visible in the vocabulary associated with these areas, which means borrowing new words and word formation (creating words). Examples are chat and chatować (a chat, to chat), or Google and googlować (Google, to google). Recently exploited foreign borrowings have mostly been of English origin and although they differ in terms of their levels of assimilation, they are quite readily recognisable (e-biznes, deadline, surfować). Linguists are noticing a gradual de-Slavicisation of the Polish language (Waszakowa, 2005; Majchrzak, 2015), which in itself is an element of the general process of European languages unification. In the studied names, however, a different tendency can be observed - whereas in the first group $17.7 \%$ of words did come from English (mobilny, free style), in group B, words of English origin constitute only $4.9 \%$. This means that there has been an oversaturation of English lexicon and the use of words such as mobilny, master or matrix, no longer elicit the desired effect. The differences between the analysed groups of names are presented in Table 1.

Table 1. Selected elements differentiating company names

\begin{tabular}{|l|c|c|}
\hline \multicolumn{1}{|c|}{ Criterion } & Group A ( $=130)$ & Group B ( $=144)$ \\
\hline Name of the owner & $38.5 \%$ & 0 \\
\hline Names with words of English origin & $17.7 \%$ & $4.9 \%$ \\
\hline Names with other words of foreign origin & $20.8 \%$ & $53 \%$ \\
\hline Terms concerning the characteristics of location & $13.1 \%$ & $70.8 \%$ \\
\hline Terms concerning the characteristics of service & $12.3 \%$ & $20.1 \%$ \\
\hline Names classified as original & $46.2 \%$ & $10.4 \%$ \\
\hline
\end{tabular}


Significant changes of note here concern the departure from informing who is providing the service towards specifying where the service is provided. Thus, it can be said that names went from individuality to universality, because a name such as Zakład Fryzjerski Danuta Chmara (Haidressing Establishment Danuta Chmara) (typical of group A) - original as it may be - says nothing. However, the name Świat Włosa (World of the Hair) says a lot - world, so everything that is accessible; of one hair - so each hair is treated individually and so, most probably, is each customer. An even more telling name is Alchemia Włosów (Alchemy of Hair) - alchemy, so turning something ordinary into gold. In the second group of names, as has already been mentioned, the word studio appeared most frequently, being a place associated with artists and also with film (film studio). Of course, a film studio is also associated with celebrities who have amazing hair stylists at their disposal, which makes such a place worth visiting.

What is therefore significant is the departure from words of English origin and the return to borrowings from French (stylizacja, wizaż, ambasada - "stylization", "visage", "embassy"), Latin (impresja, instytut, klinika - "impression", "institute", "clinic"), or Greek (akademia - "academy"). This means that qualities such as professionalism, experience, focus on the customer and uniqueness of the offer gained in value; such connotations would not be ensured by the owner's name, which has thus been replaced with synonyms of expertise and quality. While assessing linguistic innovations, a few criteria can be considered:

- sufficiency - the innovation complements the native language;

- economy - the innovation allows something to be expressed in a better, more precise way;

- functionality - the innovation is accepted because it conforms to the norm of a given language (Markowski, 2012, pp. 21-28).

It seems that in the analysed names, economic efficiency plays a major role, so the words used in the name are to better convey the message sent by the owner. Thanks to words such as akademia, klinika or salon, communication becomes more efficient, which means that the recipient understands the name according to the sender's intention (Zboralski, 2000, p. 57). From the perspective of originality, names can be divided into transferred (secondary) and formed (primary). The first group includes metaphorical names, i.e. those which are simultaneously names of something (someone) else. In the second group, there are names specially created for a given company or product. Among the 274 names analysed, only four $(1.5 \%)$ were of primary character: Fryzjer Do-Na (Do-Na Hairdresser), Lufien Mobilny Fryzjer (Lufien Mobile Haidresser), Wizażysta-Stylista-Fryzjer Lemo (Lemo MUA-StylistHairdresser), and Keraty Nowe Prostowanie Wtosów (Keratine Hair Straightening; a play on words: the adjective keratynowe is split into a meaningless keraty and the adjective nowe, which means "new"). All other names were constructed on the basis of already existing words and so they are secondary in character. 


\section{Conclusions}

This article aimed to determine the kind of changes occurring in company names from the perspective of language and marketing communication. The conducted analysis shows that as far as the originality of names is concerned, in group A (130 establishments) 60 names (46.2\%) were classified as original. In this group originality, understood as uniqueness, resulted from the fact that the names contained the first and last names of the owners, so the names did not repeat. In group B (144 companies with the word hair/hairs in their names), there were only 15 (10.4\%) original names. The lack of originality stems from two premises: the names no longer contain the names of owners, and very often they use words such as "studio", "stylization", "academy" or "clinic". The names have thus ceased to be original. This is also confirmed by the analysis of the primary or secondary character of names - among the 274 companies, only four names $(1.5 \%)$ were primary, which means that certain words were created solely for the purposes of the name. However, it should be stated that names became more efficient in terms of marketing communication, as the words "studio" or "academy" carry a lot of content and connote expertise and knowledge, as well as elite. Therefore, a company name evokes positive reactions and associations, which is very important in the first contact linking a customer and a company.

It can be also stated that company names result from linguistic fashion - until recently many of them contained the word "mobile" but now they include such terms as "studio" or "clinic". The research confirms the initial thesis that entrepreneurs search for original (unique) names in order to distinguish themselves on the market, but they are motivated by linguistic trends and not actual originality.

The conducted study concerned the hairdressing industry only, and the sample of 274 names is not representative of the population of small businesses. Researching one industry only is therefore a limitation of this study. To obtain comprehensive results, similar research should be conducted in other areas of economic activity. Moreover, the analysis presented in this article refers to language changes, and in terms of the name effectiveness, the study could be deepened by including the opinions of clients. However, the obtained results support the conclusion that company names are undergoing a transformation and their communicative capacities are improving.

\section{References}

Alserhan, B.A., \& Alserhan, Z.A. (2012). Naming businesses: names as drivers of brand value. Competitiveness Review: An International Business Journal, 22(4). DOI: org/10.1108/10595421211247169.

Andruszkiewicz, K. (2011). Marketing. Podręcznik akademicki. Toruń: Towarzystwo Naukowe Organizacji i Kierownictwa.

Chmielewska-Muciek, D. (2017). Diagnoza kontekstu komunikacyjnego w przedsiębiorstwach. Annales Universitatis Mariae Curie-Skłodowska, sectio H-Oeconomia, 51(3). DOI: 10.17951/h.2017.51.3.7. 
Dell'Era, C. et al. (2008). Language mining: Analysis of the innovation of dominant product languages in design-intensive industries. European Journal of Innovation Management, 11(1).

DOI: org/10.1108/14601060810845213.

Fox, R. (2011). Naming an organisation: A (socio)linguistic perspective. Corporate Communications: An International Journal, 16(1). DOI: org/10.1108/13563281111100980.

Majchrzak, O. (2015). Anglicyzmy w polskim dyskursie naukowym. Acta Universitatis Wratislaviensis, nr 3672, Kształcenie językowe, 13(23), pp. 73-90.

Markowski, A. (2012). Kultura języka polskiego. Warszawa: PWN.

Rotfeld, H.J. (2008). Brand image of company names matters in ways that can't be ignored. Journal of Product \& Brand Management, 17(2). DOI: org/10.1108/10610420810864739.

Saunders, J., \& Guoqun, F. (1996). Dual branding: how corporate names add value. Marketing Intelligence \& Planning, 14(7). DOI: org/10.1108/02634509610152682.

Stownik Języka Polskiego PWN. Retrieved from http://sjp.pwn.pl/ [access: 27.05.2019].

Spiro, J. (2010). How to choose the best name for your business. Retrieved from https://www.inc.com/ guides/2010/06/choose-the-best-name-for-your-business.html [access 27.05.2019].

Waszakowa, K. (2005). Przejawy internacjonalizacji w słowotwórstwie współczesnej polszczyzny. Warszawa: Wydawnictwo Uniwersytetu Warszawskiego.

Wilson, I., \& Huang, Y. (2003). Wine brand naming in China. International Journal of Wine Marketing, 15(3). DOI: org/10.1108/eb008763.

Zboralski, M. (2000). Nazwy firm i produktów. Warszawa: PWE. 